\section{"Jeśli już jestem komunistą, to jestem, a jak ich nie lubię, to naprawdę nie lubię". Droga Romana Zimanda do i od komunizmu}

Jan Olaszek
TEKSTY DRUGIE 2020, NR 6, S. 76-94

DOI: $10.18318 /$ td.2020.6.5 | ORCID: 0000-0002-7700-3256

W śród intelektualistów współtworzących w czasach PRL opozycję była duża grupa dawnych komunistów. Niemający takich doświadczeń Jan Józef Lipski zwracał uwagę na potrzebę opisania tego wątku w historii polskiej inteligencji przez kogoś, kto wcześniej komunizm popierał'. Najlepszego kandydata na autora dostrzegał w Romanie Zimandzie ${ }^{2}$. Przez wiele lat obaj

1 Niezrozumiały i przerażający amok. Rozmowa z lanem lózefem Lipskim, w: J. Trznadel Hańba domowa, Wydawnictwo Test \& Zakłady Wydawnicze "Versus", Lublin 1990, s. 301. Za pomoc w trakcie prac nad tekstem dziękuję Michałowi Przeperskiemu, Pawłowi Sasance ¡ Tomaszowi Siewierskiemu.

2 Na temat biografii Romana Zimanda zob. Biogram Romana Zimanda, W: R. Zimand "Wnocy od 12 do 5 rano nie spałem". DziennikAdama Czerniakowa - próba lektury, wstęp J. Zieliński, oprac. P. Sieniuć, Wydawnictwo IBL, Warszawa 2014; B. Dorosz Roman Zimand, w: Współcześni polscy pisarze i badacze literatury. Słownik biobibliograficzny, red. J. Czachowska i A. Szałagan, t. 9: W-Z, WsiP, Warszawa 2004; K. Biernacki Roman Zimand, w: Encyklopedia Solidarności. Opozycja w PRL 1976-1989, red. G. Waligóra, Ł. Sołtysik, K. Dworaczek, L. Próchniak, M. Zwolski, IPN, Warszawa 2019; D. Siwicka, Przedmowa, w: R. Zimand
Jan Olaszek - dr, historyk, pracownik Instytutu Studiów Politycznych PAN i Instytutu Pamięci Narodowej. Badacz opozycji w PRL. Autor książek "Nieliczni ekstremiści."Podziemna Solidarność w propagandzie stanu wojennego (2010), Rewolucja powielaczy (2015), Przeciw PRL. Szkice z dziejów opozycji demokratycznej (2017), Jan Walc. Biografia opozycjonisty (2018), Podziemne dziennikarstwo (2018) i Podziemna sieć społeczna (2020). Współautor książki Holokaust, pamięć, powielacz (2020). 
pracowali w Instytucie Badań Literackich PAN, a znali się jeszcze dłużej. Początkowo Lipski nie mógł przekonać się do przemiany Zimanda ze stalinisty w przeciwnika systemu³ , potem jednak zaprzyjaźnili się i właśnie Zimanda uznał za kogoś, kto może podołać tematowi zaangażowania całej formacji w komunizm, wskazując m.in. na to, że umiał on spojrzeć na własne doświadczenia z odpowiedniego dystansu $u^{4}$.

Tymczasem Zimand, choć o komunizmie pisywał bardzo dużo, na ogół unikał bezpośrednich odniesień do własnych doświadczeń. Badacz literatury Artur Hellich zwracał uwagę na jego skłonność do przemycania wątków autobiograficznych w tekstach na inne tematy ${ }^{5}$. Niemniej nie są one w stanie spełnić takiej roli, jaką spełniłyby wspomnienia. Bezpośrednie przekazy na temat zaangażowania Zimanda w stalinizm najczęściej pochodzą od innych osób. W wielu wspomnieniach pojawia się on najpierw jako stalinowski hunwejbin, a potem jako fundamentalny antykomunista, niezwykle krytyczny wobec swojej przeszłości. Wynikałoby z tego, że na tle ludzi o podobnych biografiach wyróżniał się zarówno radykalizmem zaangażowania w komunizm, jak igłębokością późniejszej przemiany, co czyni jego przypadek wartym bliższego zbadania. Celem artykułu jest uchwycenie drogi jego bohatera „do i od komunizmu"6 - analiza motywacji towarzyszących zaangażowaniu Zimanda w komunizm, przedstawienie jego zaangażowania i późniejszej przemiany.

Roman Zimand urodził się w 1926 roku we Lwowie w bardzo bogatej i umiarkowanie tradycyjnej rodzinie żydowskiej’. Po latach wspominał, że

Materiał dowodowy. Szkice drugie, wybór i oprac. D. Siwicka, Instytut Literacki, Paryż 1992; D. Siwicka Roman Zimand, w: Opozycja w PRL. Słownik biograficzny 1956-89, red. J. Skórzyński, P. Sowiński, M. Strasz, t. 2, Ośrodek Karta, Warszawa 2002; Roman Zimand w: W. Wincławski Słownik biograficzny socjologii polskiej, t. 4, Wydawnictwo Naukowe UMK, Toruń 2011; ). Błażejowska, Trudna biografia. Roman Zimand "Leopolita” (1926-1992), "Biuletyn IPN” 2020 nr 7-8; J. Olaszek, "Harcownik w świecie zawodowców". Roman Zimand jako badacz literatury i pisarz polityczny, „Stan Rzeczy" 2019 nr 1.

3 Ł. Garbal Jan Józef Lipski. Biografia źródłowa, t. 1: 1926-1968, IPN, Muzeum Literatury im. Adama Mickiewicza w Warszawie, Warszawa 2018, s. 188, 499.

4 Niezrozumiały i przerażający amok, s. 301-302.

5 A. Hellich Gryz autobiografią: przemilczenia, intelektualizacje, parodie, Wydawnictwo IBL, Warszawa 2018, s. 142-146, 152-153. Jeden z rozdziałów tej książki dotyczy właśnie wątków autobiograficznych w tekstach Romana Zimanda.

6 Zob. J. Kuroń Wiara i wina. Do i od komunizmu, Niezależna Oficyna Wydawnicza, Warszawa 1990.

7 R. Zimand Gatunek: podróż, „Kultura” 1983 nr 10, s. 31, 41; tegoż Gatunek podróż (dok.) „Kultura” $1983 \mathrm{nr} 11$, s. 14, 17, $20,23$. 
jego późniejsza działalność komunistyczna była zaprzeczeniem tego, co wyniósł z domu i ze szkoły ${ }^{8}$.Źródeł powojennego zaangażowania Zimanda poszukiwać należy w tym, co wydarzyło się w czasie II wojny światowej. Wiosną 1940 roku jego ojciec, Bernard Zimand, został aresztowany przez Sowietów, a następnie zamordowany ${ }^{9}$. Wkrótce Roman i jego matka, Klara Zimand, zostali wywiezieni w głąb ZSRR - do obwodu kustanajskiego w Kazachstanie $^{10}$. Przez pierwsze półtora roku młody Zimand pracował w kołchozie w niezwykle trudnych warunkach klimatycznych. Ukończył tam trzecią klasę gimnazjalną w szkole prowadzonej przez ambasadę rządu RP na uchodźstwie oraz cztery semestry technikum felczerskiego ${ }^{11}$. W czasie zesłania zgłosił się do armii generała Władysława Andersa, w której spędził jednak tylko cztery miesiące na przełomie lat 1941-1942 ${ }^{12}$. Powodem były szykany na tle żydowskiego pochodzenia, które go tam spotkały ${ }^{13}$. Tego typu sytuacje nie należały wówczas do rzadkości ${ }^{14}$.

8 A. Hellich Gryz autobiografiq, s. 148.

9 Listy Katyńskiej Ciąg dalszy. Straceni na Ukrainie. Lista obywateli polskich zamordowanych na Ukrainie na podstawie decyzji Biura Politycznego WKP(b) i naczelnych władz państwowych ZSRR z 5 marca 1940 roku, red. M. Tarczyński, Komitet, Warszawa 1994, s. 112. R. Zimand, Gatunek: podróż, s. 41-42.

DK IBL PAN, sygn. 714, akta osobowe Romana Zimanda, sygn. 714, bp, życiorys Romana Zimanda, 21 XII 1957; Archiwum Akt Nowych, Archiwum Szkół Partyjnych 43/133, życiorys Romana Zimanda, 3 III 1949, bp; AAN, KC PZPR, Centralna Kartoteka, XX/17.190, życiorys Romana Zimanda, 22 VIII 1945, k. 8; tamże, życiorys Romana Zimanda, 19 VII 1954, k. 31.

AAN, KC PZPR, Centralna Kartoteka, XX/17.190, życiorys Romana Zimanda, 22 VIII 1945, k. 8; DK IBL PAN, akta osobowe Romana Zimanda, sygn. 714, bp, życiorys Romana Zimanda, 21 XII 1957.

D. Siwicka Przedmowa, s. 7; M. Głowiński Roman Zimand (16 listopada 1926 - 6 kwietnia 1992), „Pamiętnik Literacki" 1992 z. 1, s. 263; M. Głowiński, G. Wołowiec Czas nieprzewidziany. Długa rozprawa bez pana, wójta i plebana, Wielka Litera, Warszawa, 2018, s. 67-68; Biblioteka Narodowa, Zakład Rękopisów i Starodruków, kolekcja Michała Głowińskiego, wspomnienie o Romanie Zimandzie, s. 4-5; AAN, KC PZPR, CK, XX/17.190, pismo kierownika Wydziału Aktywu Zarządu Głównego Związku Akademickiego Młodzieży Polskiej do KC PZPR, 18 II 1949, k. 22-23.

Zob. K. Kersten Problem Żydów w Polskich Siłach Zbrojnych w ZSRR i na Wschodzie w kontekście stosunków polsko-żydowskich w czasie Il wojny światowej, w: Polacy - Żydzi - komunizm. Anatomia półprawd. 1939-1968, Niezależna Oficyna Wydawnicza, Warszawa 1992, s. 25, 33 i in.; T. Gąsowski Pod sztandarami Orła Białego: kwestia żydowska w Polskich Siłach Zbrojnych w czasie II wojny światowej, Księgarnia Akademicka, Kraków 2002, s. 58-59 i in.; J. Schatz The Generation: The Rise and Fall of the Jewish Communists of Poland, Lund University Departament of Sociology, Lund 1989 s. 212-217. 
Z pewnością ta historia mogła stanowić istotny kontekst późniejszych wyborów Zimanda ${ }^{15}$. We wspomnieniu dotyczącym dzieciństwa we Lwowie pisał on z jednej strony o antysemityzmie jako czymś stale obecnym, $\mathrm{z}$ drugiej o dość harmonijnym współistnieniu różnych kultur ${ }^{16}$. Był w tym element idealizacji krainy lat dziecinnych i przeciwstawienia ich czasom powojennym, które po zerwaniu z komunizmem oceniał jednoznacznie krytycznie, jednak jego życie w II RP raczej nie było zdominowane przez doświadczenie antysemityzmu, na co wpływ mógł mieć status majątkowy rodziny. Z tym większym szokiem wiązały się zapewne szykany, z którymi zetknął się w czasie krótkiego pobytu w wojsku. Czy był to jedyny czynnik? Wydaje się, że nie. Doświadczenie antysemityzmu ze strony Polaków badacze uznają za jeden z ważniejszych czynników wpływających na akces do ruchu komunistycznego wielu polskich Żydów w okresie przedwojennym ${ }^{17}$. Jednocześnie niewątpliwie w przypadku tych osób pochodzenia żydowskiego, które komunistami zostały po wojnie, nie można nie brać pod uwagę skutków polityki nazistowskich Niemiec i zagłady Żydów. W momencie zakończenia wojny dla młodych Żydów dotychczasowe świadomie przeżyte doświadczenia wiązały się głównie z Zagładą, co wpływało na ich otwartość na idee rewolucji i budowania nowego porządku ${ }^{18}$. Tym bardziej, że ich dawny świat właściwie przestał istnieć. Komunizm jako pogromca nazizmu wielu osobom zaczął się jawić jako alternatywa. Trzeba w tym miejscu wspomnieć, że Dawid, brat Romana Zimanda, został rozstrzelany przez Niemców w momencie likwidacji getta w Żółkwi' ${ }^{19}$. Ofiarami Zagłady była też znaczna część dalszej rodziny.

Nie sposób stwierdzić, w którym dokładnie momencie w poglądach Romana Zimanda nastąpiły przewartościowania, które sprawiły, że stał się przekonanym komunistą. Czy stało się to jeszcze w Kazachstanie, po epizodzie u Andersa, czy w czasie krótkiego pobytu w Żółkwi, gdzie poznał historię brata? Może decydujący okazał się widok odbudowywanej po wojnie Polski?

15 BN, ZRiS, kolekcja Michała Głowińskiego, wspomnienie o Romanie Zimandzie, s. 5-6. Por. M. Głowiński Roman Zimand, s. 263; M. Głowiński, G. Wołowiec Czas nieprzewidziany, s. 67-68.

16 R. Zimand Gatunek: podróż, s. 44.

17 Zob. J. Schatz The Generation, s. 91-93; M. Szumiło, Roman Zambrowski 1909-1977. Studium z dziejów elity komunistycznej w Polsce, IPN, Warszawa 2014, s. 47. 
Jedna z niewielu spisanych wypowiedzi Zimanda na ten temat odnosi się m.in. do wpływu doświadczenia wojny:

Myślę, że dla pokolenia urodzonego między 1920 a 1930 rokiem podstawowy mechanizm samooślepienia, bez którego nie można było zostać bolszewikiem, związany jest z wojną. Ja, jak wielu, którzy ją przeżyli, miałem nadmiernie rozbudzoną potrzebę uporządkowania raz na zawsze wszystkiego, co jest dobre a co złe. Komunizm dawał tę jasność, która potem dla mnie okazała się ciemnością. ${ }^{20}$

Bardzo prawdopodobne, że jednym z elementów owego nowego uporządkowania świata miało być to, żeby żydowskie pochodzenie przestało być „obciążeniem" i powodem zagrożenia.

W opublikowanym w drugim obiegu eseju Piołun i popiót (czy Polacy i Żydzi wzajem się nienawidza? ) Zimand polemizował z postrzeganiem antysemityzmu jako głównej przyczyny stosunkowo dużego odsetka Żydów i Polaków żydowskiego pochodzenia wśród przedwojennych polskich komunistów ${ }^{21}$. Dostrzegał natomiast kilka specyficznych cech kultury żydowskiej, które mogły kierować ludzi w niej wyrosłych w tę właśnie stronę. Jedną z takich cech było przekonanie, że lewica nie może być antysemicka. Zimand uważał to przekonanie za fałszywe. Podawał przykłady antysemityzmu wielu czołowych postaci ruchów lewicowych na świecie ${ }^{22}$. Inny czynnik widział w legalizmie charakterystycznym jego zdaniem dla kultury żydowskiej. Skutkować miał on przekonaniem części Żydów, że problem antysemityzmu można rozwiązać środkami prawnymi i że będzie to możliwe właśnie w systemie komunistycznym, z czym Zimand polemizował w ostrych słowach, pisząc o „beznadziejnych głupcach"23. Wydaje się, że pozwalał sobie na formułowanie tak surowych ocen, dlatego że zdawał sobie sprawę, iż w sposób czytelny dla odbiorcy odnosić się mogły również do niego. Mogłoby to świadczyć o tym, że kiedyś podzielał przekonanie, iż komunizm może ochronić Żydów przed antysemityzmem.

B. Łopieńska, E. Szymańska Stare numery, Alfa, Warszawa 1990, s. 30.

R. Zimand Piołun i popiół (czy Polacy iŻydzi wzajem się nienawidzą?), Oficyna Wydawnicza Pokolenie, Warszawa 1987, s. 16.

Tamże, s. 16-17.

Tamże, s. 17-18. Por. P. ŚpiewakŻydokomuna, s. 166. 
Zimand podkreślał, że w jego ocenie najistotniejszy był specyficzny status asymilowanych Żydów, którzy starali się uciec od swoich korzeni ${ }^{24}$. Biorąc pod uwagę dostrzeżoną przez Artura Hellicha skłonność Zimanda do przemycania w tekstach wątków autobiograficznych, założyć można, że obie motywacje akcesu do komunizmu - ucieczka przed antysemityzmem i ucieczka przez żydowskością - nie były mu obce.

Matka Zimanda do tworzącego się komunistycznego porządku miała bardzo negatywny stosunek. „Byłem bardzo złym synem i bardzo się tego wstydzę. Można było sobie przecież powiedzieć, daj spokój, myśli jak żona fabrykanta, ale to jest przecież twoja matka, niech sobie myśli, co chce" wspominał po latach ${ }^{25}$. Klara Zimand przez kilka lat mieszkała w Bytomiu, następnie w grudniu 1948 roku wyemigrowała do Francji ${ }^{26}$, by po kilku latach osiąść w Izraelu. Brat Romana Zygmunt, który służył w armii Andersa, po wojnie zamieszkał w Wielkiej Brytaniii ${ }^{27}$. To, że po doświadczeniach represji ze strony Sowietów wobec najbliższej rodziny i wobec siebie samego Zimand mógł stać się przekonanym komunistą, wpisywało się w szersze zjawisko pozostawania przy wierze w komunizm mimo aresztowań, zsyłek i pobytów w łagrze. Pozwalały na to rozmaite racjonalizacje.

Słowa o „żonie fabrykanta” wskazują na wiarę w komunizm jako ustrój sprawiedliwości społecznej i równych szans. W cytowanej wyżej refleksji nad własnymi motywacjami znaleźć można również następujące słowa:

No cóż, lewicowa szajba odbijała w latach 30. różnym intelektualistom, ale to nie jest usprawiedliwienie Romana Zimanda. Nic w mojej rodzinie nie skłaniało mnie do tego, żeby zostać bolszewikiem - mój ojciec był właścicielem tartaku i fabryki parkietu. Trudno dziś zrozumieć ten palący wstyd, że jest się bogatym, a wkoło są ludzie bardzo biedni. Tylko pytanie: jakie konsekwencje się wyciąga z tego uczucia W [19]45 r. miałem dziewiętnaście lat, a w tym wieku człowiek powinien już wiedzieć, jakie uczynki są dobre, a jakie złe".28

24 R. Zimand Piołun i popiół, s. 18-20, 29-30. Zob. analizę tego tekstu: M. Tomczok Zatrucie. Piołun i popiół... trzydzieści lat później, ,ZZagłada Żydów. Studia i materiały” 2017 nr 1, s. 690-703. B. Łopieńska, E. Szymańska Stare numery, s. 29-30. AAN, KC PZPR, CK, XX/17.19o, ankieta Romana Zimanda dla aktywu partyjnego, 2 II 1949, k. 15. Tamże, k. 16. 
Wziąć pod uwagę należy również inne niż motywacje, np. wpływ autorytetów ze starszego pokolenia, chęć pozyskania korzyści materialnych i zrobienia kariery, świadomość braku alternatywy dla rządów komunistycznych w powojennej Polsce (niekiedy łączona z nadzieją na ich odmienność od sytuacji w ZSRR), brak pełnej wiedzy o zbrodniach systemu, strach, zaślepienie wiarą $\mathrm{w}$ ideologię czy poczucie konieczności odbudowania życia po wojnie ${ }^{29}$. Zapewne część z tych motywacji Zimand mógł podzielać. Wiarę w nowy ustrój wzmacniać mogła świadomość, że zaangażowanie w działalność pozwoli mu odegrać istotną rolę w życiu politycznym, mieć na coś wpływ, osiągnąć pewną pozycję. Sam po latach przyznawał, że bez zaangażowania w komunizm nie pracowałby na uniwersytecie i nie byłby dziennikarzem, a więc nie można powiedzieć, że nie odnosił korzyści ${ }^{30}$. Przyjechał do Polski jako człowiek nieposiadający właściwie niczego. Zaangażowanie pozwoliło mu znaleźć dla siebie miejsce. Bez zaangażowania nie byłaby możliwa szybka kariera dziennikarska i organizacyjna. Jednocześnie Zimand stał się człowiekiem fanatycznie wierzącym w ideologię komunistyczną. Trzeba wziąć pod uwagę jego młody wiek. Wielu ludzi z jego pokolenia niezwykle mocno i ideowo angażowała się wówczas w budowę nowego porządku. Bardzo zachęcały ich do tego ówczesne władze ${ }^{31}$.

Zimand niemal od razu po przyjeździe do Polski w czerwcu 1945 roku wstąpił do Związku Walki Młodych, czyli młodzieżowej przybudówki Polskiej Partii Robotniczej. Na początku sierpnia został przeniesiony do Wrocławia, gdzie objął dość wysokie stanowisko w Zarządzie Wojewódzkim ZWM². Tam już zgłosił akces do PPR i w październiku został przyjęty ${ }^{33}$. Jednocześnie rozpoczął pracę w „Trybunie Dolnośląskiej”, organie tamtejszego komitetu

29 J. Olaszek Dwie próby rozliczenia się środowiska literackiego ze stalinizmem, „Polska 1944/45-1989. Studia i Materiały" 2019 t. XVII, s. 77-98.

M. Wierzbicki Zwiqzzek Młodzieży Polskiej i jego członkowie. Studium z dziejów funkcjonowania stalinowskiej organizacji młodzieżowej, Wydawnictwo ISP PAN, Wydawnictwo Trio, Warszawa 2006, s. 390 .

AAN, KC PZPR, CK, XX/17.190, życiorys Romana Zimanda, 22 VIII 1945, k. 8; tamże, pismo kierownika Wydziału Aktywu ZG ZAMP do KC PZPR, 18 II 1949, k. 22-23; AAN, ASP, 43/133, życiorys Romana Zimanda, 3 III 1949, bp.; AUW, k. 1230, akta pracownicze Romana Zimanda, podanie Romana Zimanda o pracę na Uniwersytecie Warszawskim, 12 V 1950, bp.

$33 \mathrm{AAN}, \mathrm{KC}$ PZPR, CK, XX/17.190, kwestionariusz Romana Zimanda dla członków i wstępujących do PPR, 22 VIII 1945, k. 6.; AAN, ASP, 43/133, życiorys Romana Zimanda, 3 III 1949, bp. 
wojewódzkiego PPR. Jesienią 1946 roku zapisał się na wstępny rok studiów na Wydziale Humanistycznym Uniwersytetu i Politechniki we Wrocławiu. Po jego ukończeniu zaczął studiować socjologię $e^{34}$. Wstąpił też do Akademickiego Związku Walki Młodych „Życie”, komunistycznej organizacji studenckiej35.

Zimand bardzo mocno zaangażował się w budowę ustroju komunistycznego w Polsce, propagowanie towarzyszącej temu procesowi ideologii i zwalczanie jej rzeczywistych bądź domniemanych przeciwników (w praktyce często oznaczało to formułowanie oskarżeń wobec koleżanek i kolegów na różnego rodzaju zebraniach). Był postrzegany jako działacz niezwykle zaangażowany, choć jednocześnie pojawiały się wobec niego zarzuty o to, że nie potrafi współpracować z innymi, co przynajmniej dwukrotnie w końcu lat 40. ściągnęło na niego kłopoty. Na początku marca 1948 roku m.in. właśnie z tego powodu musiał odejść z "Trybuny Dolnośląskiej” i zrezygnować z funkcji pełnionej w AZWM „Życie”. Zapadła decyzja o przeniesieniu Zimanda do Warszawy i skierowaniu go do pracy w młodzieżowym tygodniku „Po Prostu”36. W stolicy Zimand kontynuował studia socjologiczne na Wydziale Filozoficzno-Społecznym Uniwersytetu Warszawskiego. Działał w uczelnianych strukturach PPR (potem w PZPR) ${ }^{37}$. Mimo dobrego pióra i talentu dziennikarskiego znowu dość szyblko zaczął mieć kłopoty w pracy. W „Po Prostu” był niecały rok - do 1 lutego 1949 roku $^{38}$. Wtedy został zatrudniony jako korektor w dziale wydawniczym Szkoły Partyjnej przy KC PZPR („Dwulatce”) ${ }^{39}$. Jeszcze podczas pracy w redakcji „Po Prostu” został oskarżony o opowiadanie „antyradzieckich" dowcipów ${ }^{40}$. Sprawa trafiła

34 Archiwum Uniwersytetu Warszawskiego, 10611, akta studenckie Romana Zimanda, życiorys Romana Zimanda, bd, bp.

AAN, KC PZPR, CK, XX/17.19o, ankieta Romana Zimanda dla aktywu partyjnego, 2 II 1949, k. 17; tamże, życiorys Romana Zimanda, 2 II 1949, k. 19; tamże, pismo kierownika Wydziału Aktywu ZG ZAMP do KC PZPR, 18 II 1949, k. 22.

AAN, KC PZPR, CK, XX/17.190, życiorys Romana Zimanda, 2 II 1949, K. 19; tamże, pismo kierownika Wydziału Aktywu ZG ZAMP do KC PZPR, 18 II 1949, k. 22. AAN, KC PZPR, CK, XX/17.19o, ankieta Romana Zimanda dla aktywu partyjnego, k. 17. AAN, ASP, 43/133, życiorys Romana Zimanda, 3 III 1949, p.

AAN, ASP, 43/133, pismo kierownika Wydziału Ogólnego do Referatu Personalnego, 1 || 1949 , bp.; tamże, pismo kierownik Wydziału Ogólnego do Referatu Personalnego, 26 IX 1950 r. bp; tamże, zaświadczenie kierownika Archiwum Szkół Partyjnych, 30 IV 1986, bp.; AAN, KC PZPR, CK, XX/17.190, życiorys Romana Zimanda, 2 II 1949, k. 20. 
przed Centralną Komisję Kontroli Partyjnej KC PZPR. Zimanda obwiniono o „obcość ideologiczną”, a jako kontekst podniesiono jego nieumiejętność dogadywania się ze współpracownikami ${ }^{41}$. Zarzucono mu też „współdziałanie w intryganctwie” i „mieszczański tryb życia” ${ }^{42}$, wskazywano m.in. na jego „burżuazyjne pochodzenie” $i$,intrygi w życiu osobistym”, wypomniano ukrywanie pobytu w armii Andersa, to, że "cała rodzina” znajdowała się za granicą, oraz „jawnie wrogie nastawienie wobec Polski Ludowej” jego matki, która kilka tygodni wcześniej wyjechała z kraju ${ }^{43}$. Zespół Orzekający CKKP w grudniu 1949 roku zdecydował o wykluczeniu Romana Zimanda z PZPR i zwróceniu się do Wydziału Personalnego KC PZPR o zwolnienie go z pracy w aparacie partyjnym. Ponieważ stamtąd jednak dotarły do CKKP pozytywne opinie, pozwolono Zimandowi pozostać członkiem organizacji młodzieżowych, gdzie - jak pisano - „aktywną pracą będzie mógł naprawić swoje błędy, a po pewnym czasie ubiegać się o ponowne przyjęcie do Partii" ${ }^{44}$. Zimandowi udało się jednak uniknąć wyrzucenia z PZPR i utraty pracy. W maju 1950 roku podczas zebrania podstawowej organizacji partyjnej na Uniwersytecie Warszawskim wygłosił samokrytykę. W związku z tym, a także ze względu na młody wiek i doniesienia o poprawie postawy, w sierpniu 1950 roku CKKP zdecydowała, że kara zostanie zamieniona na "surową naganę"45.

Doświadczenie to raczej nie wywołało w Zimandzie wątpliwości dotyczących wyznawanych poglądów, nastąpiła wręcz pewna radykalizacja jego postawy. W pierwszej połowie lat 50. należał do relatywnie niewielkiej grupy osób uznawanych za fanatycznych zwolenników marksizmu, uczestniczących w atakach na kolegów i wykładowców. We wrześniu 1950 roku został zatrudniony na uczelni na stanowisku asystenta (jeszcze jako student, co w tamtych czasach było częste). Jego przełożonym był Adam

41 Tamże.

AAN, KC PZPR, CK, XX/17.19o, pismo redaktor naczelnej „Po Prostu” Krystyny Walczak do Wydziału Personalnego KC PZPR w sprawie Romana Zimanda, 18 II 1949, k. 24-25. AAN, KC PZPR, CK, XX/17.19o, pismo kierownika Wydziału Aktywu ZG ZAMP do KC PZPR, 18 II 1949, k. 23. AAN, KC PZPR, CK, XX/17.190, uchwała Centralnej Komisji Kontroli Partyjnej PZPR, 10 XII 1949 r., $\mathrm{k} 26$. k. 2. Na temat tej historii zob. B. Łopieńska, E. Szymańska Stare numery, s. 32; BN, ZRiS, akc. 18180/3, kolekcja Michała Głowińskiego, wspomnienie o Romanie Zimandzie, s. 4. 
Schaff ${ }^{46}$. To on prawdopodobnie ściągnął wkrótce Zimanda do Instytutu Kształcenia Kadr Naukowych przy KC PZPR, który powstał na bazie wspomnianej „Dwulatki" ${ }^{\prime 4}$. Instytucja ta miała kształcić młode pokolenia marksistowskich naukowców, którzy później pracowaliby na uczelniach w całym kraju ${ }^{48}$.

Charakterystyki Zimanda sporządzane w czasie jego pobytu w tej instytucji z jednej strony wskazywały na pewne wady jego postawy i charakteru (niezdyscyplinowanie, arogancję,,zarozumialstwo”), z drugiej - na ewolucję, którą w czasie pobytu w szkole partyjnej miał przejśc c $^{9}$. W związku z tym W 1954 roku struktury partyjnie zaopiniowały pozytywnie ${ }^{50}$ i zaakceptowały ${ }^{51}$ wniosek o cofnięcie nagany.

Wypowiedzi Zimanda na zebraniach różnych instancji organizacji partyjnej w IKKN były pryncypialne. Krytykował chłopów spółdzielczych niewywiązujących się ze zobowiązañ ${ }^{52} \mathrm{i}$ aktywistów partyjnych "kaleczących" język polski ${ }^{53}$. Na jednym ze spotkań zwrócił uwagę na „brak samodzielności i przesadne oglądanie się na kierownika naukowego" części aspirantów, wymieniając z nazwiska jedną z koleżanek ${ }^{54}$, na innym powiedział, że wygłoszo-

46 AUW, Akta pracownicze Romana Zimanda, K 1230, świadectwo pracy Romana Zimanda, 31 VII 1951, bp; DK IBL PAN, akta osobowe Romana Zimanda, sygn. 714, bp; życiorys Romana Zimanda, 21 XII 1957.

DK IBL PAN, akta osobowe Romana Zimanda, sygn. 714, bp; życiorys Romana Zimanda, 21 XII 1957.

B. Bińko Skąd przychodzili, dokąd zmierzali... aspiranci pierwszego rocznika Instytutu Kształcenia Kadr Naukowych przy KC PZPR, w: Komunizm: ideologia - system - ludzie, red. T. Szarota, IPN, Warszawa 2001, s. 178. Zob. też: B. Bińko Instytut Kształcenia Kadr Naukowych przy KC PZPR-narzędzie ofensywy ideologicznej w nauce i szkolnictwie wyższym, „Kultura i Społeczeństwo” 1996 nr 2, s. 192-204.

49 AAN, ASP, 97/306, charakterystyka tow. Zimanda Romana, 4 IX 1953 bp.; tamże, charakterystyka tow. Zimanda Romana, 10 IX 1953, bp.; tamże, charakterystyka tow. Zimanda Romana, 5 VIII 1954, bp.;

AAN, ASP, 24/18, opinia sekretarz Komitetu Partyjnego INS Marii Małeckiej w sprawie podania Romana Zimanda do CKKP o skreślenie nagany partyjnej 13 VI 1954, k. 39; tamże, opinia Albina Kani w sprawie podania Romana Zimanda do CKKP o skreślenie nagany partyjnej, 7 V 1954, K. 40.

51 AAN, ASP, 97/306, charakterystyka tow. Zimanda Romana, 5 VIII 1954, bp.

52 AAN, ASP, protokół z zebrania OOP Katedry Materializmu-Dialektycznego i Historycznego 15 XII 1953, bp. AAN, ASP, 24/7, protokół z zebrania POP przy INS, 7 IV 1954, bp.

54 AAN, APS, 24/8, protokół z zebrania OOP pracowników i aspirantów Katedry Materializmu Dialektycznego i Historycznego IKKN, 13 I 1953, bp. s. 3-4. W teczce oznaczonej sygnaturą 24/9 znajduje się identyczny protokół datowany na 13 I 1954. 
ne przez jednego z kolegów zagajenie było „zbyt szkolarskie” i nie służyło jej rozwinięciu ${ }^{55}$. Tego rodzaju oceny osobom, których dotyczyły, mogły wtedy bardzo zaszkodzić.

Sam po latach opowiadał o swojej postawie w tamtych czasach następująco: „Na uczelni musieli się mnie bać. Jak biłem, to biłem po oczach. Bo, jeśli już coś robię, to robię porządnie i do końca. Jeśli już jestem komunistą, to jestem, a jak ich nie lubię, to naprawdę nie lubię ${ }^{156}$. Wspominał przy tym opublikowany na łamach „Myśli Współczesnej” tekst ostro atakujący Stanisława Ossowskiego ${ }^{57} \mathrm{i}$ podkreślał, że napisał go z własnej woli ${ }^{58}$. Wskazywał także inne przykłady ataków: rozprawę z Witoldem Jedlickim (za krytykę oficjalnej wykładni ma temat Jugosławii) na zebraniu ZMP, udział w usunięciu z uniwersytetu studenta o pochodzeniu robotniczym pod zarzutem "lewactwa” oraz wytknięcie innemu studentowi tego, że jego wujek i ojciec byli przedwojennymi oficerami ${ }^{59}$. Wspomnieć jeszcze można o atakach prasowych Zimanda. Czesława Miłosza nazwał „zdrajcą”, a Ludwika Flaszena - „świętą dziewicą ideologiczną”, której „kiedyś pastuchy złożą korne hołdy" ${ }^{\text {60 }}$. Roman Loth, który czasie studiów zetknął się z Zimandem jako partyjnym agitatorem, wspominał: „Reprezentował wówczas bardzo radykalnie rewolucyjny komunizm, a - trzeba przyznać - był mówcą inteligentnym i żarliwym”' . "Tacy jak on nas wykończą" - miał o nim powiedzieć Henryk Markiewicz, z którym Zimand konsultował swoje pierwsze prace naukowe w czasie pobytu w IKKN ${ }^{62}$.

Zimand regularnie pisywał do prasy. Jego propagujące socrealizm teksty ukazywały się na łamach m.in. „Nowej Kultury” i „Trybuny Ludu”63. W tej ostatniej został zatrudniony na stałe w dziale kultury w październiku 1954

55 AAN, APS, 24/8, 24/8, protokół z zebrania OOP przy Katedrze Materializmu Dialektycznego i Historycznego 26 XI 1953, bp.

B. Łopieńska, E. Szymańska Stare numery, 30.

Zob. R. Zimand, rec. S. Ossowskiego U podstaw estetyki, „Myśl Współczesna” 1951 nr 2, s. 278-290.

B. Łopieńska, E. Szymańska Stare numery, 30.

Tamże, s. 30-32. A. Hellich Gry z autobiografig, s. 148.

R. Loth Zapamiętane. Z lat dawnych Instytutu Badań Literackich PAN, IBL, Warszawa 2015, S. 124.

63 Tamże, s. 148. 
roku. ${ }^{64}$ Praca w organie pasowym KC PZPR dla niespełna trzydziestoletniego gorliwego marksisty, którego głównym zajęciem było pisanie, z pewnością oznaczała duże osiągnięcie. Jednocześnie świadczyła, że Zimand cieszył się zaufaniem władz partyjnych, i sprawa nałożenia na niego kary partyjnej poszła w niepamięć.

W czasie dyskusji prasowych prowadzonych na fali odwilży w grudniu 1956 roku Zimand przyznał, że był stalinistą, „zwłaszcza w latach 1949$-1953^{\prime \prime 65}$. Nie wiemy, jak rozumiał pojęcie „stalinista”. Z pewnością przemiany w jego poglądach zachodziły powoli i nie w sposób ciągły. Na niejednoznaczny obraz jego postawy od 1954 do wiosny 1956 roku składa się wygłoszony w kwietniu 1955 roku referat o Odwilży Ilji Erenburga wskazujący na zalety tego dzieła ${ }^{66}$, odpowiedź na krytykę poezji stalinowskiej sformułowaną przez krytyka literackiego Jana Błońskiego ${ }^{67}$, ocena Poematu dla dorostych Adama Ważyka jako utworu „politycznie błędnego", ale zasługującego na „poważną dyskusję" ${ }^{\text {"68 }}$, oraz głos przeciwko rozliczeniom personalnym w czasie dyskusji nad Obrona Grenady Kazimierza Brandysa ${ }^{69}$. Z pewnością niezwykle istotną cezurą w biografii Zimanda był maj 1956 roku, kiedy trafił on ponownie do zespołu redakcyjnego „Po Prostu”. Wówczas jednak było to już zupełnie inne pismo - z niewyróżniającego się na tle reszty prasy organu ZMP tytuł ten jesienią 1955 roku zmienił się w pismo rewolucyjnie nastawionych młodych ludzi, którego teksty miały istotne znaczenie dla kształtu odwilży w Polsce i otwierały dyskusje na różne tematy ${ }^{70}$. Część współpracowników postrzegała Zimanda jako kogoś nasłanego przez władze, relacji w zespole nie ułatwiały cechy jego charakteru".

64 DK IBL PAN, akta osobowe Romana Zimanda, sygn. 714, bp; życiorys Romana Zimanda, 21 XII 1957.

65 R. Zimand Kilka zwykłych dni we Wrocławiu..., "Po Prostu” 9 XII 1956, nr 50, s. 2.

66 J.Zawieyski Dzienniki, t. 1: Wybór z lat 1955-1959, red. A. Knyt, współpr. M. Czoch, Ośrodek Karta, Warszawa 2011, s. 91.

67 D. Nałęcz Lata 1949-1956, w: Czasopisma społeczno-kulturalne w okresie PRL, red. U. Jakubowska, IBL, Warszawa 2011, s. 135-136.

68 T. Chrząstek Na kulturalnym froncie. Analiza zawartości tygodnika "Nowa Kultura"1950-1963, IPN, Warszawa 2016, s. 194.

69 Ł. Garbal Jan Józef Lipski, s. 268.

W. Władyka Lata 1956-1960, w: Czasopisma społeczno-kulturalne w okresie PRL, s. 145.

71 D. Rafalska Jan Olszewski - reporter i publicysta tygodnika „Po Prostu” w latach 1956-1957, w: Nie tylko niezłomni i kolaboranci... Postawy dziennikarzy w kraju i na emigracji 1945-1989, red. T. Wol- 
Wydarzeniem, którego trudno nie uznać za istotny kontekst dla późniejszej zmiany postawy Zimanda, był Czerwiec' 56 .Zimand miał okazję z bliska przyjrzeć się wówczas masowemu protestowi robotników i jego niezwykle brutalnej pacyfikacji - wszedł w skład kilkuosobowej delegacji, która udała się do Poznania ${ }^{72}$. Był przerażony tym, co zobaczył. „Nagle przekonałem się, że czterdziestotysięczna organizacja partyjna Poznania nie istnieje. Najzwyczajniej w świecie jej nie ma. Czyli w ciągu jednego dnia przekonałem się, że nie ma Pana Boga. Jest bezpieka, jest wojsko, ale nie ma partii" - wspominał po latach ${ }^{73}$. Kierujący w owym czasie Wydziałem Propagandy KC PZPR Andrzej Werblan wspominał, że w „Po Prostu” na pierwszej stronie miał ukazać się duży artykuł Zimanda zatytułowany L'ordre règne à Poznań (Porządek panuje w Poznaniu), co stanowiło nawiązanie do meldunku wysłanego po zdławieniu Komuny Paryskiej i znanej w Polsce karykatury przedstawiającej tłumienie powstania listopadowego przez kozakó $\mathrm{w}^{74}$. Z powyższego wspomnienia wynikałoby, że Zimand po powrocie z Poznania był już nastawiony bojowo. Jako jedna z wersji do cenzury trafił tekst Poznań - pierwsze obserwacje, który podpisali wraz z nim Stanisław Chełstowski i Włodzimierz Godek. Ton artykułu był dość wyważony, zwracano uwagę, że generalnie w mieście panował porządek, choć zdarzały się wybryki chuligańskie. „Incydenty te spotykały się ze zdecydowanym odporem robotniczego trzonu manifestacji" - stwierdzano. Jednocześnie według zaprezentowanej wersji wydarzeń robotnicza demonstracja miała zamienić się w „zbrojny bunt przeciwko władzy ludowej”. W artykule podkreślono, że bunt nie służył „sprawie klasy robotniczej”, i wyrażono podejrzenia, że miał zorganizowany charakter ${ }^{75}$. Mimo takich konkluzji tekst nie ukazał się w tej formie. Wydrukowany artykuł nosił tytuł

Sza, P. Wójtowicz, IPN, Warszawa 2014, S. 155; J. Błażejowska Ta historia wciq̨ż trwa. Wspomnienia Jana Olszewskiego, Zysk i S-ka, Poznań 2019, s. 256, 362-363; B. Łopieńska, E. Szymańska Stare numery, s. 65, 123.

D. Rafalska Między marzeniami a rzeczywistościq. Tygodnik "Po Prostu" wobec głównych problemów społecznych i politycznych Polski w latach 1955-1957, Neriton, Warszawa 2008, s. 175; Ł. Grzelczak Poznański Czerwiec 1956. Walka o pamięć w latach 1956-1989, Wydawnictwo Nauka i Innowacje, IPN, Poznań 2016, s. 102-104.

A. Werblan Polska Ludowa. Postscriptum. Rozmawia Robert Walenciak, Iskry, Warszawa 2019, S. $144-145$. 
Pierwsze uwagi. Według dziennikarzy tego pisma miał wyróżniać się na tle innych, choć autorzy nie mogli napisać wszystkiego. Analizy tego artykułu prowadziły do wniosku, że tak nie było ${ }^{76}$. Wymowa tekstu niewiele różniła się od wymowy innych doniesień prasowych, gdyż mało uwagi poświęcono w nim ofiarom, a jednocześnie artykuł wpisywał się w wizję protestu jako efektu działań „wroga zmierzającego do obalenia władzy"7". Pisano, że wydarzenia czerwcowe mogą być wykorzystane przez „kołtuna” i „dzierżymordę”, co można interpretować jako aluzje do partyjnej „konserwy"78. Można uznać to za wyraz przynależności Zimanda do zwolenników zmian.

Świadectwem zaostrzania się pióra Zimanda latem 1956 roku - i jednocześnie, jak się wydaje, łagodzenia niewiedzącej, co powinna zrobić cenzury - jest opublikowany kilka tygodni później na łamach „Po Prostu” tekst Próba o ludowładztwie, w którym Zimand podawał w wątpliwość istnienie w Polsce „dyktatury proletariatu”. Powoływał się przy tym na słowa Stalina definiujące stosunki produkcji jako stosunki „współpracy i wzajemnej pomocy”, po czym przechodził do wątpliwości, które z przyjęcia takiego założenia wynikają. „Rodzi ono szereg pytań: co to znaczy konkretnie współpraca lub wzajemna pomoc między, dajmy na to, Ministerstwem Przemysłu Maszynowego a Zakładami im. Stalina w Poznaniu?" - pytał, z pewnością nieprzypadkowo odwołując się akurat do tego przykładu ${ }^{79}$.

Zimand współtworzył to, co przybrało nazwę Października'56, na różnych polach. Pisywał teksty, występował na rozmaitych forach, brał udział w wiecach, spotykał się z ludźmi z najróżniejszych kręgów, przekazywał informacje na temat bieżących wydarzeń. Osoby, które stykały się z nim jesienią 1956 roku, odnotowywały w dziennikach lub wspominały po latach jego dużą aktywność w tym czasie, radykalizm i rewolucyjne nastawienie ${ }^{80}$. Należał

76 Ł. Grzelczak Poznański Czerwiec, s. 103-104. Por. B. Łopieńska, E. Szymańska Stare numery, s. 67-68.

D. Rafalska Między marzeniami a rzeczywistościq, s. 176; Ł. Grzelczak Poznański Czerwiec, s. 104.

P. Sasanka, Władza, prasa i dziennikarze między XX Zjazdem KPZR a Październikiem 1956 r., w: Nie tylko „Po Prostu”. Prasa w Polsce w dobie odwilży 1955-1958, red. M. Przeperski, P. Sasanka [w druku].

R. Zimand Próba o ludowładztwie „ „Po Prostu” 22 VII 1956 nr 30, s. 2, 7. Omówienie tez kilku tekstów Zimanda z 1956 roku zob. D. Rafalska Między marzeniami a rzeczywistościq, s. 34-36, 197-198.

80 J. Błażejowska Ta historia wciąż trwa, s. 362; J. Urban Jerzy Urban o swoim życiu rozmawia z Marta Stremeckq, Warszawa 2013, s. 93; W. Woroszylski Dzienniki, t. 1: 1953-1982, Ośrodek Karta, Warszawa 2017, s. 145-147; J.J. Lipski Dzienniki 1954-1957, wstęp A. Friszke, oprac. Ł. Garbal, Więź, Warszawa 2010, s. 73, 146-147; A.K. Wróblewski Dzienniki zabrane przez bezpiekę, Agora, War- 
już go grupy „wściekłych” - dziennikarzy najostrzej domagających się daleko idących zmian ${ }^{81}$. W tekstach i wypowiedziach na różnych forach przekraczał granice tego, co było dopuszczalne dla władzy ${ }^{82}$. Postulował wyłączenie spod kontroli PZPR całych sfer życia publicznego, dążył do „ludowładztwa” rozumianego nie tylko jako przeciwieństwo kapitalizmu, ale również stalinizmu. Krytykował tempo zmian i odwoływanie się do ideologii marksistowskiej przy piętnowaniu postulatów reform: „Jeżeli moje tezy są nieprawdziwe, to nie dlatego, że są niezgodne z marksizmem, a dlatego, że nie stanowią adekwatnego opisu rzeczywistości społecznej w Polsce. A zatem dyskutujmy o tym, jak jest naprawdę, a nie o tym, co jest zgodne"83. Wraz z Jerzym Kossakiem i Ryszardem Turskim poddał krytyce politykę ZSRR i radzieckie relacje z Polską, ganiąc kopiowanie wzorców ze wschodu oraz nierówność w relacjach między partiami komunistycznymi ${ }^{84}$.W obliczu wydarzeń na Węgrzech zwłaszcza ta ostatnia kwestia była wymowna. Sam Zimand w tekście Sprawy robotników całego świata wprost odniósł się do interwencji ZSRR, podkreślał, że wydarzenia na Węgrzech i to, co działo się w Polsce, postawiły wszystkich przywódców państw komunistycznych przed dylematem: opowiedzieć się za stalinizmem czy przeciwko niemu. Przypominał reakcję PZPR, która jako pierwsza partia komunistyczna na świecie „w sposób zgodny z prawdą” oceniła wydarzenia na Węgrzech ${ }^{85}$. Na początku grudnia 1956 roku Zimand pozwolił sobie na rozważenie zasadności likwidacji PZPR. Wbrew temu, co mu zarzucano, nie opowiadał się za tym rozwiązaniem, pisał, że to byłoby zbyt łatwe, ale samo postawienie problemu było wyjątkowe, podobnie jak to, że opowiadając się przeciwko likwidacji PZPR, nie odwoływał się do argumentów ideologicznych, lecz do kwestii geopolitycznych ${ }^{\mathbf{8 6}}$.

szawa 2008, s. 79-82; K. Modzelewski Zajeździmy kobyłę historii. Wyznania poobijanego jeźdźca, Iskry, Warszawa 2016, s. 306; J. Kuroń Wiara i wina, s. 109; por. A. Friszke Anatomia buntu. Kuroń, Modzelewski i komandosi, Znak, Kraków 2010, s. 33, 35; J. Kuroń Pięć dni Października, "Aneks” $1986 \mathrm{nr}$ 43, S. 40; R. Zimand List do redakcji, "Aneks" 1987 nr 46-47, 258. M. Przeperski Odwrót od Października. Pacyfikacja prasy i dziennikarzy w latach 1956-1958, „Pamięć i Sprawiedliwość" $2015 \mathrm{nr}$ 28, s. 315. Archiwum Akt Nowych, Stowarzyszenie Dziennikarzy Polskich, 4/7, stenogram Plenum Zarządu Głównego Stowarzyszenia Dziennikarzy Polskich, IX 1956, bp.

83 R. Zimand Spór o przyszłość socjalizmu, „Po Prostu” 21 X 1956 nr 43, s. 7.

84 J. Kossak, R. Turski, R. Zimand Internacjonalizm, „Po Prostu” 28 X 1956, s. 2, 7.

85 R. Zimand Sprawy robotników całego świata, „Po Prostu” 4 XI 1956, s. 1-2.

86 R. Zimand Kilka zwykłych dni we Wrocławiu..., „Po Prostu” 9 XII 1956, nr 50, s. 2. 
Radykalizm ludzi takich jak Zimand szybko przestał odpowiadać Gomułce. Zdecydowaną reakcję wywołała wypowiedź Zimanda na III Krajowym Zjeździe Delegatów SDP (na przełomie listopada i grudnia 1956 roku), gdzie stwierdził, że kierownictwo partyjne nie może być traktowane jako nieomylne (tak jak w stalinizmie), można się z nim nie zgadzać i że to prasa może mieć rację $^{87}$. Kilka dni później Gomułka na spotkaniu z Prezydium SDP obszernie odniósł się do tej wypowiedzi. Zastrzegał, że wybrał ją jako przykład, gdyż wyłaniać się z niej miały wszystkie cechy „ujemnej strony działalności prasy" ${ }^{18}$. Kilka miesięcy później, w czasie obrad IX Plenum KC PZPR, piętnując "rewizjonistów”, wymienił Leszka Kołakowskiego, Wiktora Woroszylskiego i Romana Zimanda ${ }^{89}$. Napiętnowanie to nie zmieniło nastawienia Zimanda, który tak jak inni dziennikarze „Po Prostu” miał coraz większe kłopoty z cenzurą ${ }^{90}$. Ostatecznie skończyło się to likwidacją pisma jesienią 1957 roku.Zimand, podobnie jak wiele osób z redakcji, został wówczas wyrzucony z PZPR ${ }^{91}$. Powodem miało być „odejście od ideologii socjalistycznej i udział w grupowej walce z linią partii"92. Mimo takiego końca rewolucyjnego zaangażowania Zimand przez pewien czas wierzył jeszcze w możliwość naprawy "ustroju socjalistycznego" od wewnątrz. Od decyzji o wyrzuceniu go z PZPR bezskutecznie próbował się odwoływać w liście skierowanym do Gomułki³. Formacja ludzi nazywanych „rewizjonistami” istniała w kręgach polskiej inteligencji jeszcze przed ponad dekadę - za jej koniec uznaje się na ogół Marzec'68 - ale Zimand porzucił te przekonania w ciągu kilku pierwszych lat po Październiku. Dużo później krytycznie oceniał swoje poglądy z czasów odwilży i okresu tuż po niej: „Byłem zajadłym rewizjonistą, czyli tym, który

87 W. Władyka Lata 1956-1961, s. 158.

88 AAN, SDP, 3/107, wypowiedź I Sekretarza KC PZPR na spotkaniu z członkami Prezydium Stowarzyszenia Dziennikarzy Polskich, 10 XII 1956, bp.

89 K. Rokicki Literaci. Relacje między literatami a władzami PRL w latach 1956-1970, IPN, Warszawa 2011, S. 125.

Ł. Garbal Jan Józef Lipski, s. 332, 343, J. Keńska Burżuazyjne wymysły "Po Prostu”, czyli potyczki tygodnika z cenzurq w 1957 roku, w: Dziennikarze władzy, władza dziennikarzom. Aparat represji wobec środowiska dziennikarskiego 1945-1990, red. T. Wolsza, S. Ligarski, IPN, Warszawa 2010, s. 129-130; D. Rafalska Agonia "Po Prostu”. Próby zachowania pamięci o jednym z najpoczytniejszych tygodników lat pięćdziesiątych XX wieku, w: Dziennikarze władzy..., s. 103.

K. Rokicki Literaci, s. 130.

D. Siwicka Przedmowa, s. 8. 
nie zadając sobie pytań dotyczących podstawowych założeń teoretycznych, uznając je za dobre, sądzi, że należy i może uczynić ten ustrój idealnym przez takie czy inne zabiegi"94.

Jego azylem stał się IBL PAN, gdzie został zatrudniony na początku 1958 roku i pracował do końca życia jako badacz literatury. Równolegle prowadził działalność opozycyjną, stając się potem czołowym publicystą prasy drugiego obiegu ${ }^{95}$. W krytyce komunizmu poszedł znacznie dalej niż większość ludzi o podobnych doświadczeniach. Jego poglądy - chociaż trudno jednoznacznie stwierdzić, od którego dokładnie momentu - można określić jako zdecydowanie antykomunistyczne (z czasem stał się bardzo krytyczny wobec lewicy jako takiej). Podkreślić trzeba, że przekładało się to nie tylko na oceny postaw innych osób, ale również, a może przede wszystkim, siebie samego. Zimand nie stosował wobec swojej przeszłości taryfy ulgowej. Autorkom książki o „Po prostu" mówił:

Nie mam do nikogo pretensji. Nikt mnie nie oszukał. Każdy z nas oszukiwał sam siebie i innych, którzy albo się dawali, albo nie. Słowem każdy z nas sam sobie pierze ten mózg [...] Mówi się, że byliśmy ideowi. Ale jak to się mierzy tę ideowość? Jest to bardziej okoliczność obciążająca niż usprawiedliwiająca. Bo z punktu widzenia skuteczności procesu sowietyzacji najlepsi są ci, którzy działają w przeświadczeniu, że działają w słusznej sprawie. Mówi się, że wierzyliśmy. Czy ktoś wierzył naprawdę, czy nie - jest absolutnie nie do zbadania. Zresztą mało jest cynicznych karierowiczów. Kto to mówi sobie - zostanę komunistą, żeby zrobić karierę. Mówi się, że nie odnosiliśmy korzyści materialnych. Odnosiliśmy wszyscy. Nie zostałbym przecież asystentem bez mojego zaangażowania, koledzy z „Po Prostu” nie zostaliby dziennikarzami. Jedni mówią - wierzyłem do końca, więc wszystko jest w porządku, drudzy - nie wierzyłem nigdy, więc wszystko jest w porządku. Ja uważam, że ze mną wszystko było nie w porządku, wszystko było ze mną nie tak, jak miało być. Jest to biografia, którą trudno nosić, ale staram jak potrafię. Oto moja samokrytyka i jak każda niewystarczająca ${ }^{96}$.

B. Łopieńska, E. Szymańska Stare numery, s. 123; por. R. Zimand List do redakcji, „Aneks” 1987 nr 46-47, s. 258; W. Woroszylski Dzienniki, s. 316. wy" 16 IV 1992. 
O sile jednoznacznie krytycznego stosunku Zimanda do własnej przeszłości świadczy historia związana z jego życiem osobistym. W 1969 roku, po przejściu przez Polskę antysemickiej kampanii, z kraju wyjechała jego dziesięcioletnia córka wraz z matką?. Mimo to Zimand nie zdecydował się na emigrację. Czuł się odpowiedzialny za wprowadzenie w Polsce komunizmu. Opuszczenie kraju, póki ten ustrój nadal w nim istniał i miliony ludzi musiały w nim żyć, uważał za niemoralne. Mówił, że najpierw musi po sobie posprzątaćs8. Rozpoczął wówczas pracę nad Materiałem dowodowym - dedykowanym córce esejem poświęconym komunizmowi. Tekstu tego nie skończył, jego fragment ukazał się dopiero po jego śmierci ${ }^{99}$. Nie był jednak świadectwem własnej drogi Zimanda "do i od komunizmu”, ani drogi całej pokoleniowej formacji, na co liczył Jan Józef Lipski. Zadanie jej opisania wciąż stoi przed historykami.

D. Siwicka Przedmowa, s. 7.

98 S. Niesiołowski Roman; A. Hellich Gry z autobiografiq, s. 152-153; J. Zieliński Erudyta poprzeczny. Stare i nowe glossy do portretu Romana Zimanda, w: IBL w PRL II. Sylwetki i wspomnienia, red. E. Kiślak, IBL, Warszawa 2016, s. 205. 


\section{Abstract}

\section{Jan Olaszek}

INSTITUTE OF POLITICAL STUDIES OF THE POLISH ACADEMY OF SCIENCES (WARSAW)

INSTITUTE OF NATIONAL REMEMBRANCE

"If I'm a Communist, I Really Am One, and if I Don't Like Them, I Really Do Not Like Them": Roman Zimand's Journey Towards and Away From Communism

Olaszek outlines the development of the political engagement of Roman Zimand, a journalist, sociologist and literary scholar.Zimand, a communist at first, became a revisionist and later an oppositionist with starkly anto-Communist views. Olaszek provides a rationale for Zimand's decision and his later stance on his own past, arguing that Zimand was remarkably radical compared to people with comparable biographies and highly critical of his own life choices. This article is a contribution to the debate on the Polish intelligentsia's attitude towards communism.

\section{Keywords}

Roman Zimand, communism, Stalinism, revisionism, anti-communism 